\title{
Assessment of post-storm recovery of beaches using video imaging techniques: A case study at Gold Coast, Australia
}

\author{
Kristen D. Splinter, Darrell R. Strauss, and Rodger B. Tomlinson
}

\begin{abstract}
Ever-expanding networks of surf cameras offer a unique opportunity to monitor the coastline over large expanses at very little cost compared to traditional in situ survey methods. Here we describe and test a new coastal monitoring system maintained by CoastalCOMS Pty Ltd at their test site at Gold ${ }^{6}$ Coast, Australia. The 2-camera system monitors two highly sensitive 4-km stretches of sandy coastline adjacent to high value assets. The traditional static multi-camera set-up has been replaced by a single rotational camera. A 14-month data set, encompassing one major storm, a recovery period, and a seasonal cycle was analysed. Positive shoreline detections using the new $w^{1}$ camera system were available $64 \%$ of the time (roughly $145^{\circ}$ days of the available 226 where daily offshore significant wave heights $H_{s} \leq 1 \mathrm{~m}$ ). Comparison of the CoastalCOMS derived shorelines and in situ survey data showed a mean shoreward bias of $25.5 \mathrm{~m}$. Daily shoreline estimates were used to calculate weekly and 5-week running mean beach widths at both sites. Analysis 6 showed that both sites eroded between 15 - $22 \mathrm{~m}$ during the $\mathrm{May}_{7}$ 2009 storm and then recovered during the proceeding 5 month calm period. Distinct inter-site variability was observed between the more exposed Northern Beaches that displayed an annual shoreline cycle and very little intra-site variability and the more sheltered southern Palm Beach site that displayed large intrat site spatial variability and sensitivity to changes to both wave direction and wave height.
\end{abstract}

Index Terms-Image processing, geophysical measurementsiat remote sensing, optical image processing.

\section{INTRODUCTION}

$\mathbf{T}$ HE Gold Coast is a $35-\mathrm{km}$ stretch of sandy coastline at the south-east tip of Queensland, Australia. The region is a world-renowned tourist destination for both its famous surf breaks and golden beaches, requiring careful and ongoing management. Since the early 1960s, the local council has conducted beach profile surveys at select locations (ETA lines) along the entire length of the Gold Coast following standard in situ surveying methods applied around the world. Dry beach profiles are measured using a Leica real-time kinematic (RTK) Global Positioning System (GPS). The RTK system utilises the Smartnet GPS Reference Station Network and automatically locks on to the most suitable base. The inner surfzone is measured using a $5 \mathrm{~m}$ aluminium pole with

Manuscript received $\mathrm{xxx}$; revised $\mathrm{xxx}$. This work was funded under the $\mathrm{Fu}^{\mathbf{\beta}^{2}}$ ture Coastlines project in partnership with Griffith University and Queenslands Smart State Innovation.

K. D. Splinter, D. R. Strauss, and R. B. Tomlinson are with the Griffith Centre for Coastal Management; Griffith University, Gold Coase, QLD, 4216, AU. (email: k.splinter@griffith.edu.au, d.strauss@griffith.edu.aub6 r.tomlinson@griffith.edu.au) reflective prism and Leica theodolite and overlaps both the dry and offshore bathymetry surveys. The offshore bathymetry is measured using a $7.01 \mathrm{~m}$ Shark Cat Surveyor II with a Leica RTK GPS unit in the vessel running through Hydro Pro Navigational software with a high frequency single beam transducer attached to a Reson Navisound Echo Sounder. These have provided the basis for analysis of beach width and volume changes in support of beach protection works [1]. However, due to the cost and time associated with traditional survey techniques, beach profiles are only surveyed at irregular intervals (on average once per year at specific transects spaced between 1 and $5 \mathrm{~km}$ apart) and only provide a snapshot of the dynamic nature of the system.

Video-based monitoring is increasingly being used as an alternative method to observe the nearshore environment in both high temporal and spatial resolution [2]-[5]. Methods have been developed to estimate bathymetry [6]-[9], classify the nearshore morphology [10]-[12], study sandbar and terrace dynamics [13]-[16], estimate wave direction [17], wavelength [18], as well as breaking wave height and wave period [19]. From a coastal management perspective, the spatial and temporal variability of the shoreline (or the effective beach width) is a primary indicator of beach health and commonly included as part of post-construction monitoring of coastal engineering works [20], [21]. A number of techniques have been proposed to estimate shoreline position from videobased images [22], [23]. Early work by Plant and Holman [24] derived a method to estimate shoreline position from greyscale images based on bands of brightness associated with waves breaking at the shoreline. Alternatively, Alexander and Holman [25] used variations in image intensity between the high-tide and low-tide 10-min time-exposure (Timex, [10]) images to estimate shoreline position. With the transition to colour video, the algorithms were further refined. Color images are converted from standard Red-Green-Blue $R G B$ colour format that contain information about colour and brightness in each band to Hue-Saturation-Value $H S V$ colour space. In this way, colour is separated into $H S$ and brightness into $V$. Typical ocean values fall in the blue-green region with $0.4<H<0.6$ and low saturation $(S \sim 0.2)$, while sand falls in the yellow/red region with low hue $(0.2<H<0.3)$ and high saturation $(S \sim 0.7)$. Aarninkhof et al. [8], [26] exploited differences in $H S V$ space to estimate shoreline position based on observed differences between wet (water) and dry (sand) pixels. Shoreline detection methods using artificial neural networks [27] and those exploiting the differences between 


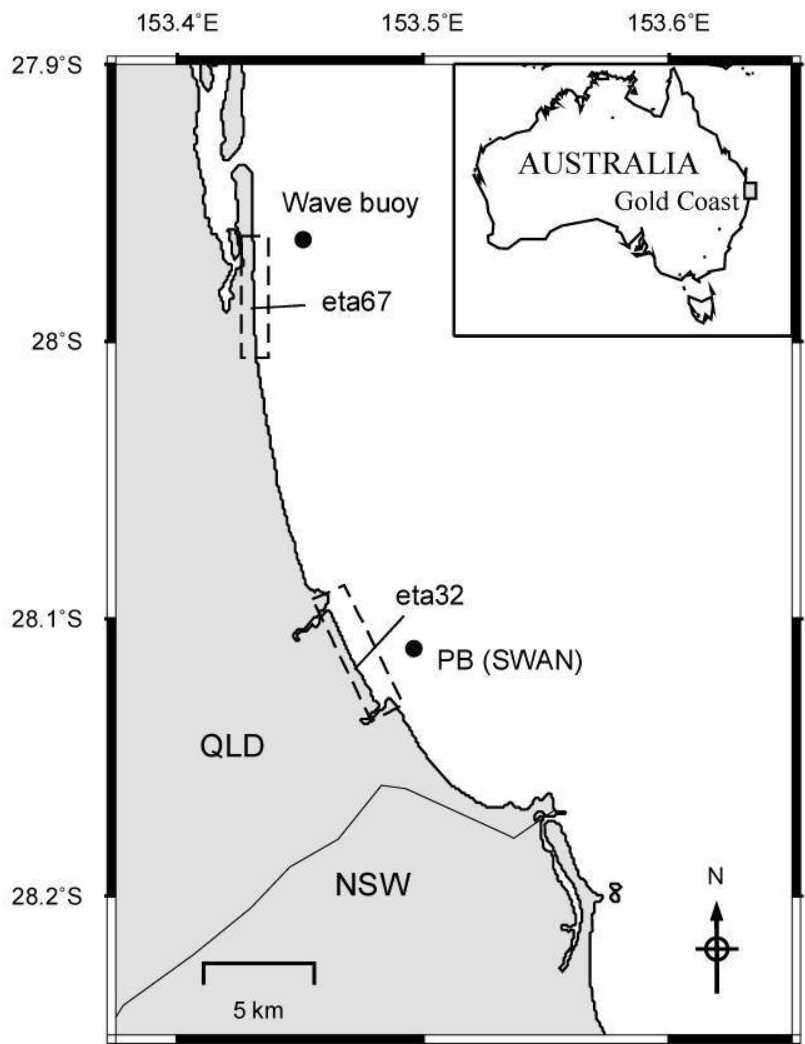

Fig. 1. Location of study site. Northern Beaches beaches with survey line ETA 67 and Palm Beach with survey line ETA 32. Gold Coast wave buoy (located in $18 \mathrm{~m}$ of water) at the north end of the coast and output from SWAN3 model used to estimate wave conditions at Palm Beach are also shown. SWAN output for the Northern Beaches is co-located with the Gold Coast buoy.

the relative amount of red and blue light observed in wets and dry pixels [20] have also been developed. The readerts is referred to Plant et al. [23] for a complete discussion of shoreline detection methods using video imagery.

In 1999, the Gold Coast City Council adopted a secondr method of shoreline monitoring with the implementation of 3 the Argus coastal imaging system [3], [4], [28] to assess the effectiveness of beach protection strategies [20], [21], [29] k25 Multi-camera systems (Fig. 2 top) were installed on high-riseso at two locations on the Gold Coast. The first site covered approximately a $4-\mathrm{km}$ stretch encompassing the survey lines ETA 67 and the beaches of Narrowneck and Surfers Paradise at the northern end of the Gold Coast (herein referred too as the Northern Beaches). The second system covered an additional 4-km stretch of coastline including survey linez ETA 32 and Palm Beach further south (Fig. 1). Each stations consisted of 4 to 5 static cameras, spanning a $180^{\circ}$ view of the coastline. Using standard photogrammetric techniques [2], thes relationship between 2D-image coordinates and 3D real-worldo coordinates was ascertained. These geo-referenced values werer then used to monitor a number of physical parameters in thes images at near-continuous sampling. For the Gold Coast, thes principal monitoring parameter used is effective beach widtho measured as the position of the shoreline with respect to at

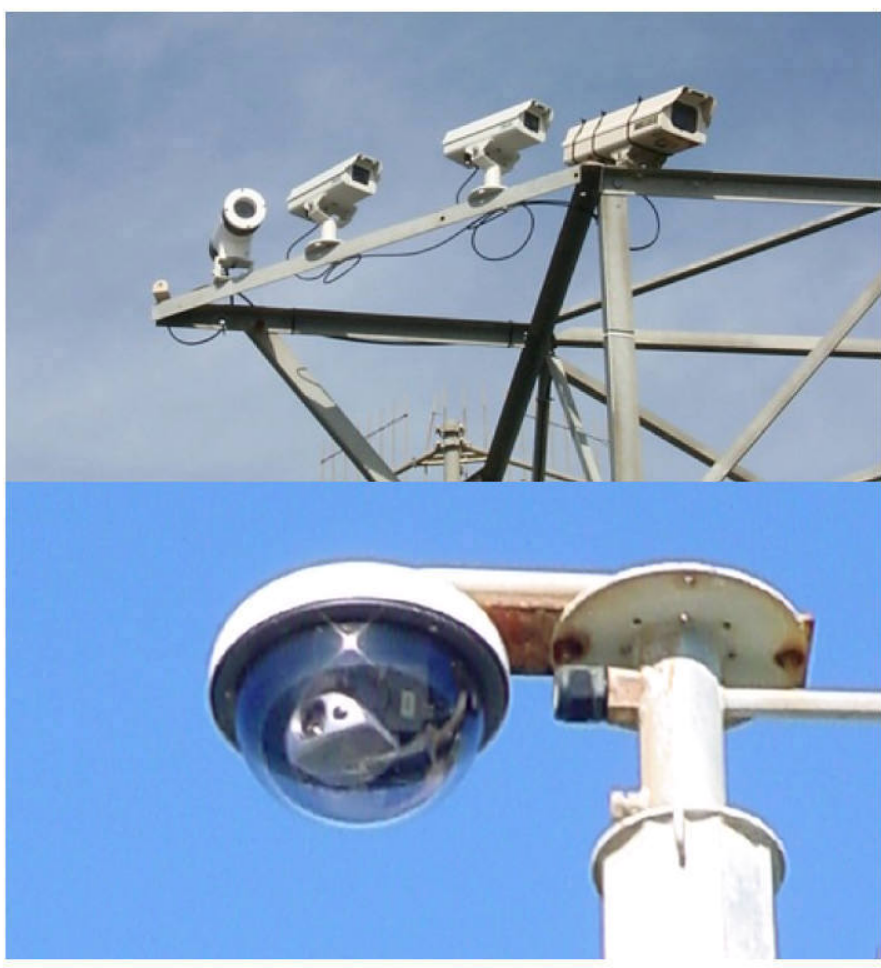

Fig. 2. Example of a traditional static multi-camera Argus system (top) and the rotational camera used by CoastalCOMS (bottom). Argus camera setup from Agate Beach, OR, USA courtesy of Rob Holman. CoastalCOMS camera from Miami, QLD, Australia.

buried seawall (A-line).

In early 2007, a second video monitoring system was installed adjacent to the Argus camera system at Narrowneck (Northern Beaches) using CoastalCOMS technology developed by Griffith University and Coastalwatch Pty Ltd. The traditional multi-camera system was replaced by a single rotating robotic camera (Fig. 2 bottom) that is remotely controlled and rotates to fixed view points at specific times. Similar to that described by Holland et al. [2], transformations between image $u, v$ and real-world $x, y$ coordinates are obtained through the Direct Linear Transformation (DLT) technique first proposed by Abdel-Aziz and Karara [30] where the z-coordinate (vertical axis) is taken identically to be 0 (corresponding to local mean sea level). While previous techniques [2] used extensive calibration to obtain highly accurate estimates of camera properties and the transformation coefficients, the CoastalCOMS methodology solves the DLT coefficients using a linear least-squares technique on an over-determined system of corresponding pixel and real-world coordinate pairs. Over a 10-month period between February and December 2007 the CoastalCOMS derived shorelines were compared against the Argus derived shorelines at the same location. Comparisons of the two shoreline data sets after applying a 7-day smoothing filter and a 10-degree polynomial interpolator showed that for $92 \%$ of the data set the CoastalCOMS derived trendline was $\pm 6 \mathrm{~m}$ of the Argus trendline (Chris Lane, pers. comm.). In late 2008, the single camera CoastalCOMS system replaced the static camera Argus system at both sites and has since been the primary method of shoreline monitoring on the Gold 
Coast.

199

The currently installed cameras are Sony SNCRZ50N, netoo worked enabled High Resolution Pan/Tilt Zoom Cameraso, 1 utilizing a 1/4 type Exwave $\mathrm{RHAD}$ interline transfer $\mathrm{CC}_{2}$ with $10 / 100$ base $\mathrm{T}$ Ethernet. They are capable of handling 3 16 user defined presets, with a repeatable preset accuracy of 4 \pm 0.064 degrees. The cameras have 340 degree pan rotatiosas and 115 degree tilt range with a minimum built in $26 \mathrm{x}$ opticado6 auto focus lens and minimum $12 \mathrm{x}$ digital zoom capabilitie $8_{0,7}$ allowing for a sampling range of 3 to $5 \mathrm{~km}$ with varyings levels of accuracy. The calibration of the robotic cameras system is achieved through a custom designed rig attachedo to the Sony designed robotic camera housing. The calibration process involves collecting Ground Control Point (GCP) datae at regular intervals within each of the camera views. Distancess between GCP points range from $50 \mathrm{~m}$ (near-field camera views) to $750 \mathrm{~m}$ (far-field camera views), with a total of 2.35 - 7 GCP points per image for the analysis period presented here. GCP data is collected via a handheld GPS unit with simultaneous image capture to relate real-world coordinates tos pixel values. Calibration is done whenever a camera is movedo or changed. For the period of analysis presented here, theo Northern Beaches had a calibration done in October 2008 and again in December 2009, while Palm Beach had calibrations in April 2009 and April 2010.

There are currently over 100 sites throughout Australia, the United States, and Europe operated by Coastalwatch that offer 3 near realtime views of the coastline and provide daily surf rez4 ports. The Gold Coast cameras operated by CoastalCOMS ares preliminary 'proof of concept' test sites that provide shorelines monitoring (via the high-mounted cameras) and wave height estimation (via the low-mounted surf cameras) [19]. As theses networks continue to expand and image processing algorithmss are refined, they can offer potential data sets for researcherso and coastal managers alike. The 14-month data set between May 2009 and June 2010 is used to test CoastalCOMaS shoreline algorithm accuracy using high-mounted cameras and analyse shoreline variability under natural wave forcing. Data4 used in the analysis is presented in Section II. Results off shoreline detection and beach width analysis for the two sites 6 are presented in Section III and further discussed in Sectios IV. We conclude with a summary of findings in Section V.238

\section{DATA}

\section{A. Site Description}

\section{3}

The Northern Beaches (Fig. 1) are a relatively open coast line exposed to waves year-round and display a cyclic nature indicative of seasonal variations in wave climate, with er@ 44 sional periods during the Australian summer (January to Mayds and accretionary periods during the milder wave conditions $a f_{6}$ Australian winter (July - October) [31]. In response to the 'Northern Gold Coast beach protection strategy' [32] a majors nourishment project $\left(1.2 \mathrm{M} \mathrm{m}^{3}\right.$ of sand) and the construction of an artificial reef [33] offshore of Narrowneck commenced ia 1999. Nourishment and the major construction was completed by the end of 2000 . Additionally, a large relic shoal from 2 a previous entrance of the Nerang River lies directly offshores and may provide a sand source in this area [34].
Palm Beach (Fig. 1) is a curved section of coastline bordered by Currumbin Creek at the south and Tallebudgera Creek and Burleigh headland to the north. It undergoes much more extensive and ongoing management that impacts the temporal evolution of the shoreline. Short groynes adjacent to 11 th Avenue $\left(y=1200 \mathrm{~m}\right.$, between Camera $L_{2}$ and $\left.N_{1}\right)$ and 21st Avenue ( $y=2200 \mathrm{~m}$, between Camera $N_{1}$ and $N_{2}$ ), as well as a training wall for Currumbin Creek at $y=-$ $600 \mathrm{~m}$ (Camera $F$ ) influence the natural longshore transport along the beach. Offshore deposits of sand from the ebbtidal delta of the creek and recirculation cells periodically transport sand onshore during more easterly and northerly wave events. This beach receives annual (minor) nourishment from the dredging of the adjacent Currumbin Creek. During this monitoring period, two nourishments took place on Palm Beach. In July 2009, 10,000 $\mathrm{m}^{3}$ of sand from the Kirra Beach Restoration Project was placed on the upper beach profile in areas where the boulder wall was exposed from the May 2009 storm (Camera $L_{2}$ ). Between August 24 and October 2, 2009, approximately $58,000 \mathrm{~m}^{3}$ of sand was placed on the upper beach between $0 \mathrm{~m}<y<500 \mathrm{~m}$ (Camera $L_{1}$ ) from annual maintenance dredging.

\section{B. Wave conditions}

Hourly wave conditions are recorded by a directional waverider buoy located in a water depth of $18 \mathrm{~m}$ at Narrowneck at the northern end of the Gold Coast (Fig. 1). The buoy is operated jointly by the Queensland Department of Environment and Natural Resources (DERM) and the Gold Coast City Council. Wave recordings include significant wave height $H_{s}$, maximum wave height $H_{\max }$, peak wave period $T_{p}$, mean wave period $T_{z}$, and peak wave direction $D_{p}$. Wave conditions $\left(H_{s}, T_{p}\right.$, and $\left.D_{p}\right)$ for the analysis period are shown in Figure 3 . The mean significant wave height for the monitoring period was $1.17 \mathrm{~m}$.

Wave conditions along the east coast of Australia originate primarily from four main sources: ocean swell, wind seas, East Coast Lows (ECLs) and Tropical Cyclones (TCs). The annual wave climate is dominated by swell generated in the Southern Ocean and Tasman Sea that impacts the coast as small to medium size, moderate to long period waves from the south to south-east [35], [36] and is responsible for an estimated net northerly sediment transport rate of $500,000 \mathrm{~m}^{3} / \mathrm{yr}$.

The long-term average significant wave height for the Gold Coast is $1.15 \mathrm{~m}$, with higher than average waves between January and May, corresponding with Australian summer and the cyclone season [37]. Increases in offshore wave heights during June and July are due to south-easterly trade winds [35], but these may not directly impact the east-facing coast depending on their angle of incidence. Wind seas are locally generated and occur mainly during the Australian summer when heating over the land generates afternoon sea breezes resulting in small, short period waves. Along the Gold Coast, ECLs are the most commonly occurring destructive events, capable of bringing large and long period waves from the east to south-east, and are often accompanied by storm surge and high rainfall. These typically occur between March - June, but 

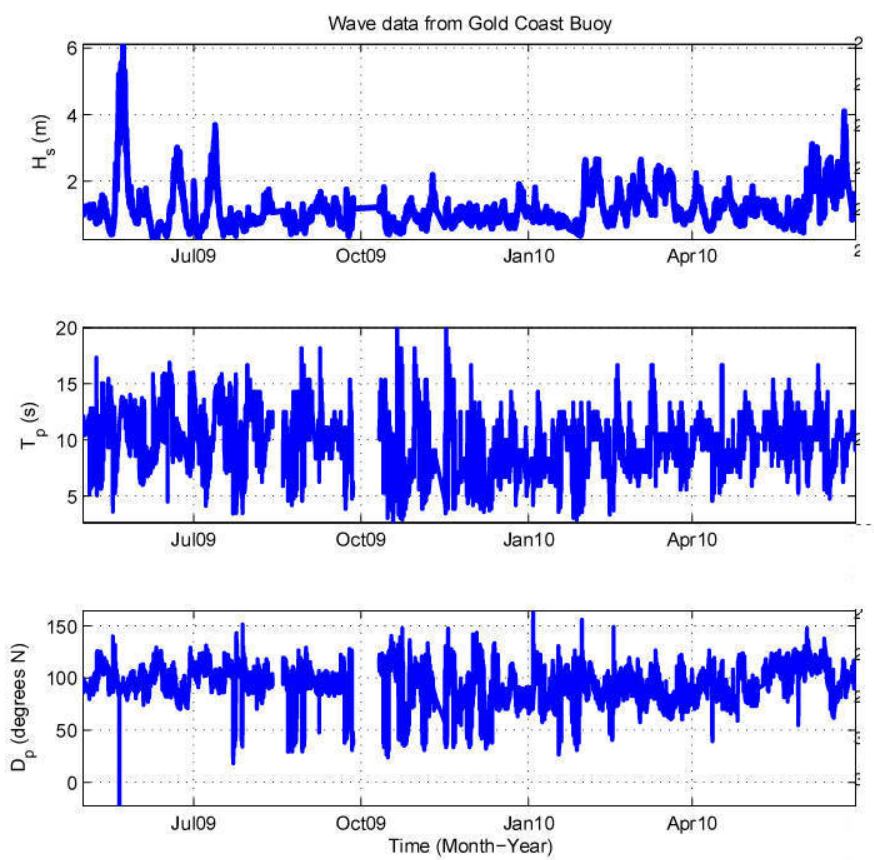

Fig. 3. Wave data from Gold Coast buoy. (top) Significant wave height. (middle) Peak period. (bottom) Peak wave direction.

can occur at any time. Tropical Cyclones rarely track as fars south as the Gold Coast, but may generate energetic east 109 north-east swell and strong winds during the late Australiati ${ }^{\circ}$ summer.

During the monitoring period, one major storm occurred ${ }^{2}$ from May 19 - 25, 2009 and was classified as an ECL (Fig. ${ }^{3}$ 3). The storm produced the second largest significant wavet height recorded at the Gold Coast buoy since recordings begati 5 in $1987\left(H_{s}=6.1 \mathrm{~m}\right)$ and a maximum wave height $H_{m a x}{ }^{316}$ $=10.6 \mathrm{~m}$. The prolonged large waves combined with storît surge caused significant erosion along much of the south ${ }^{18}$ east Queensland and northern New South Wales coast. Thie remainder of the monitoring period was relatively mild, wifla minor events in June and July of 2009 and June 2010 (Fige? 3).

Compared to the Northern Beaches, Palm Beach has ${ }^{32}{ }^{3}$ significantly smaller and more easterly wave climate due $133^{4}$ wave shadowing of the southerly waves by Point Danger $a^{25}$ the tip of the Queensland - New South Wales border (Fig. 1) [38]. Propagating offshore modeled wave conditions (froili the European Centre for Medium-Range Weather Forecasi? ${ }^{3}$ wave reanalysis (ERA-40) or NOAA's WaveWatch III) inf3 ${ }^{9}$ the coast results in an alongshore gradient of mean annuado breaking wave heights of roughly $0.5 \mathrm{~m}$ between the southers beaches and the exposed north coast [39], as well as significant2 shifts $\left(\sim 45^{0}\right)$ in wave angle [40]. Although model resultss compare well with the Gold Coast buoy data at the Northersa Beaches [41], no comparison can be made for the southeras beaches. However, the modeling efforts provide an estimateo of the inter-site variability of wave climate along the coask37 but are limited by the assumption that the dominant offshores wave climate is also the dominant nearshore wave climate ando this may significantly impact the estimated wave climate ato the southern beaches. For comparative purposes between the two monitoring sites, 3-hourly WaveWatch III offshore wave model output was propagated into the $20 \mathrm{~m}$ contour using the SWAN model. Mean wave statistics from the monitoring period measured from the buoy and model output are presented in Table I.

\section{Shoreline Position}

The inherently dynamic nature of the water-line position with respect to land requires that an appropriate sampling interval is chosen to meet the demands of the end-user [42]. For the purposes of this study we aim to analyse medium to long term behaviour of alongshore averaged sections of the shoreline. To this end we use shoreline positions obtained at selected transects spaced $40-160 \mathrm{~m}$ apart along the beach with respect to the same tidal datum (mean sea level $M S L$ ) using remote sensing techniques. The accuracy of remote sensing techniques to measure shoreline position is dependent on the camera properties, shoreline detection method, incident wave conditions, and tide levels [23], [42]. Previous work by Aarninkhof et al. [26] indicated that video-derived shorelines using the $H S V$ method had a vertical error in shoreline position of approximately $0.2 \mathrm{~m}$. This translates to a horizontal error of $6.7 \mathrm{~m}$ given an average swash zone (i.e. $\pm 1 \mathrm{~m} \mathrm{MSL}$ ) beach slope of 0.03 . The use of images obtained around MSL removes a significant portion of the tidal bias. However, the use of a single camera rotating to each view means that images are not all simultaneously taken at true MSL. For a 5-view camera system, this requires 5-minute time-exposure images to be centered around \pm 10 minutes of MSL. On the Gold Coast, this is equivalent to approximately a $7.5 \mathrm{~cm}$ change in water level over the 25 minute sampling period and translates to an estimated horizontal error of $\pm 1.25 \mathrm{~m}$ around the true MSL shoreline position. To remove shoreward bias from high wave setup, we also remove any days where the measured offshore significant wave height $H_{s}$ is greater than $1 \mathrm{~m}$ [31], thus limiting the vertical error to approximately $0.18 \mathrm{~m}$. This translates to a maximum horizontal offset due to wave setup of $5.7 \mathrm{~m}$ for the Gold Coast beaches. For the analysis period presented here 226 (of the 420) days had daily average significant wave heights of less than (or equal to) 1 $\mathrm{m}$. Summing up the above errors approximates to error bands of $+14 \mathrm{~m}$ and $-4 \mathrm{~m}$ of the true MSL contour.

Shoreline detection using the CoastalCOMS technique is similar to that proposed by Aarninkhof et al. [26] and involves a four step process. First, a 5-min Timex image is taken around local MSL (roughly equivalent to the Australian Height Datum $A H D=0$ ) once per day at each of the pre-defined view points. The colour images are then transformed into $H S V$ space. The algorithm applies a median filter to the Hue values of the converted images and then uses the Sobel edge detection method [43] to estimate shoreline pixel coordinates $u, v$ (Fig. 4). At pre-defined transects (Table II), real-world coordinates $x, y$ of the shoreline are recorded for further analysis (Fig. 4). 
TABLE I

SUMMARY OF WAVE STATISTICS FOR EACH SITE. STATISTICS FOR NORTHERN BEACHES ARE GIVEN FOR BOTH WAVE BUOY DATA AND SWAN MODEL

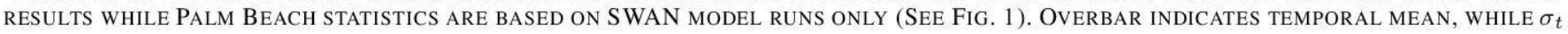
IS THE TEMPORAL STANDARD DEVIATION.

\begin{tabular}{cccccc}
\hline Site & Time & $\overline{H_{s}}(\mathrm{~m})\left(\sigma_{t}(\mathrm{~m})\right)$ & $\overline{T_{p}}(\mathrm{~s})\left(\sigma_{t}(\mathrm{~s})\right)$ & $\overline{H_{s} / T_{p} w}\left(\sigma_{t}\right)$ & $\overline{D_{p}}\left({ }^{o} \mathrm{~N}\right)\left(\sigma_{t}\left({ }^{o} \mathrm{~N}\right)\right)$ \\
\hline Northern & May - June 2009 & $1.37(1.04)$ & $10.9(1.8)$ & $4.25(3.02)$ & $98(10)$ \\
Beaches & July - December 2009 & $0.97(0.37)$ & $9.6(2.5)$ & $3.61(1.55)$ & $91(19)$ \\
Buoy & January - June 2010 & $1.27(0.51)$ & $9.5(1.6)$ & $4.60(2.00)$ & $93(14)$ \\
\hline Northern & May - June 2009 & $1.52(1.23)$ & $8.9(2.3)$ & $5.60(4.16)$ & $111(25)$ \\
Beaches & July - December 2009 & $1.03(0.50)$ & $8.1(2.6)$ & $4.58(2.38)$ & $93(40)$ \\
SWAN & January - June 2010 & $1.24(0.53)$ & $8.5(2.1)$ & $5.04(2.17)$ & $104(27)$ \\
\hline Palm & May - June 2009 & $1.30(1.20)$ & $9.0(2.3)$ & $4.78(4.10)$ & $94(26)$ \\
Beach & July - December 2009 & $0.93(0.49)$ & $8.2(2.5)$ & $4.23(2.58)$ & $80(35)$ \\
SWAN & January - June 2010 & $1.07(0.55)$ & $8.5(2.1)$ & $4.31(2.22)$ & $92(23)$ \\
\hline
\end{tabular}

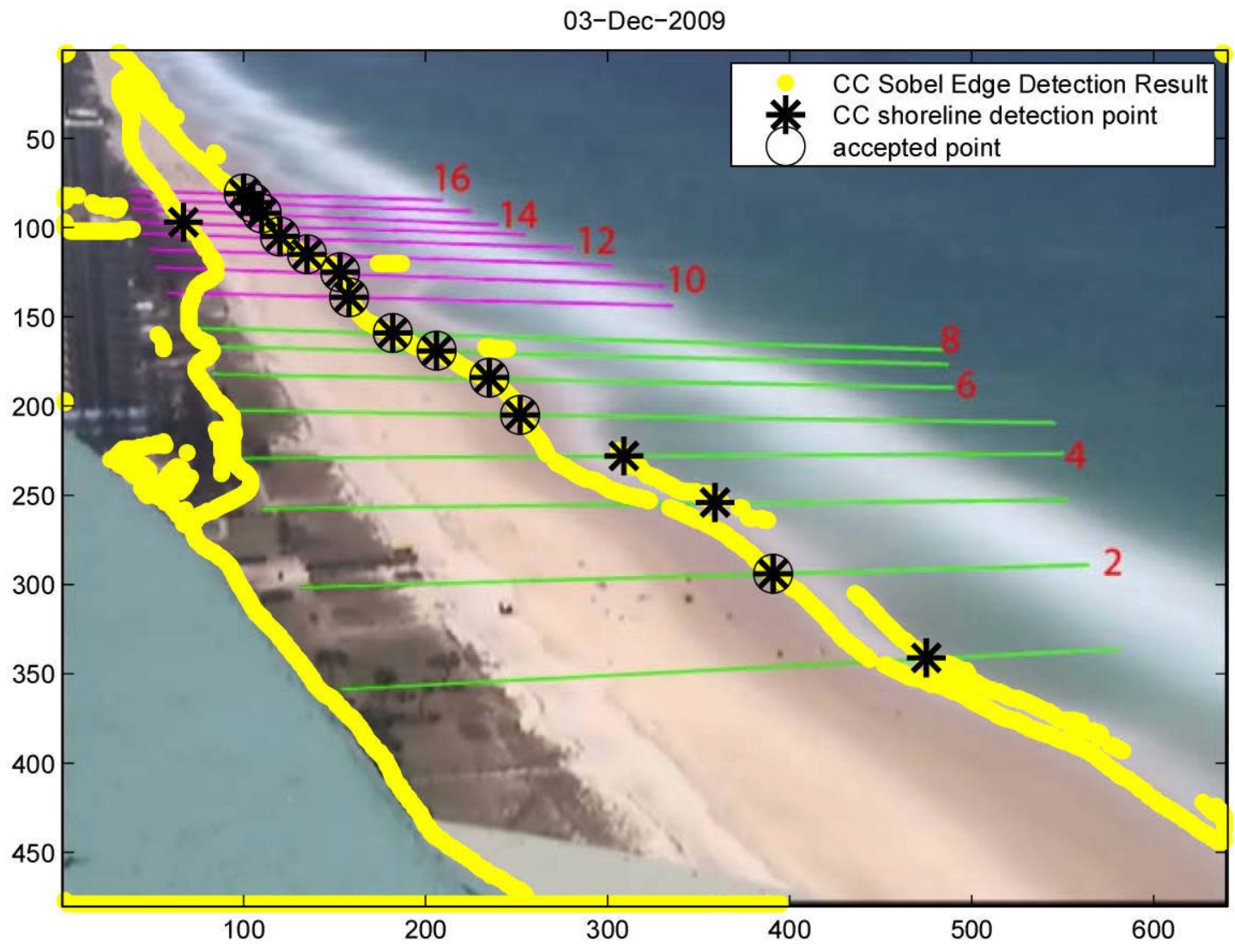

Fig. 4. Example of detected shoreline and selected transects for beach width evaluation. Image is from Dec. 3, 2009, Camera $L$, Northern Beaches. Solid yellow line represents the results of the Sobel edge detection algorithm. Black stars indicate shoreline detection for each transect and circled stars indicate what points were accepted for further analysis.

\section{RESUlts}

\section{A. Shoreline Detection}

Prior to analyzing shoreline data it is neccessary to assesso the CoastalCOMS shoreline detection methods and overa看 accuracy. A total of 420 daily images were available estimate average shoreline positions along the length of coast 3 covered by the two cameras (Figs. 5, 6). Pixel resolution is estimated using the pixel $u, v$ and real-world $x, y$ coordinate pairs from the accepted shoreline detection points. By comparing the absolute distance between shoreline data in both pixel and real-world space, we can estimate a m/pixel statistic to estimate pixel resolution. However, this approach also assumes that the DLT coefficients estimated from the 


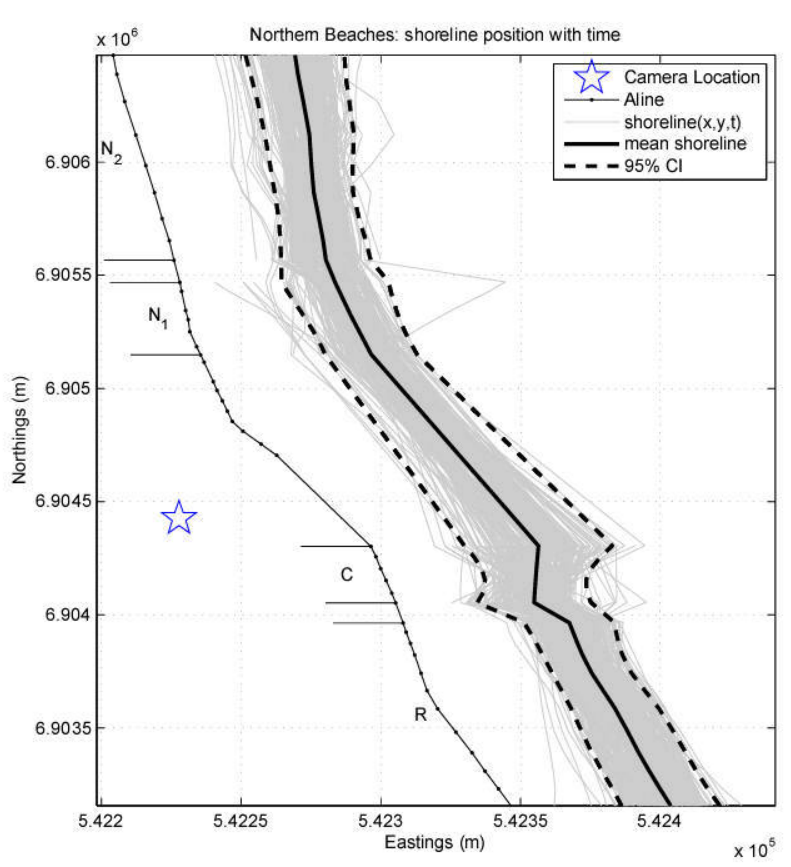

Fig. 5. Daily shorelines (grey) with temporal mean (solid black) and $95 \%$ limits (dashed) for Northern Beaches. The A-line is given by solid black line with dots. Camera location is indicated by blue star and camera view locations identified along the A-line.

linear least-squares technique are correct, and thus should be considered an estimate of combined pixel resolution and DLF 4 transformation accuracy. Statistics for each camera view apes given in Table II. For the Northern Beaches we use 3 of the 396 camera views to analyse shoreline variability, while we use add 5 at Palm Beach. The reason for this is that 2 camera vieusse $(F \& L)$ in the Northern Beaches did not contain a sufficients number of GCP data points to determine accurate DLT (pixelsøo real world transformation) coefficients for part of the analysis 1 period.

392

Within each image the shoreline data are manually checked 3 for visual accuracy and where shoreline positions are inaccass rate, usually due to false detections, they are discarded fromas the analysis (Fig. 4). The two most common causes of falseo detections resulted from the algorithm picking up well-defined offshore bars or dune vegetation lines where a sharp contrasts in hue exists in the image. For an image to be kept at leasta $50 \%$ of the transects must return positive shoreline detectionso (Figs. 7, 8). This resulted in an average shoreline detection rate of $66 \%\left(62 \%\right.$ when $\left.H_{s} \leq 1 \mathrm{~m}\right)$ for the Northern Beachesz and $63 \%$ (66\% when $H_{s} \leq 1 \mathrm{~m}$ ) for Palm Beach (Table IIans Shoreline positions are then filtered using a $250 \mathrm{~m}$ Hanning window to remove small scale features, such as beach cuspss and rip channels and fill in missing data points. Beach widtho is then calculated as the perpendicular distance from selected 7 reference points to the shoreline. Along the Gold Coast, thes A-line, which represents the location of a buried boulder wadds spanning most of the coast, is used as a fixed geo-referencee baseline for determining beach width. An alongshore-averaged beach width for each analysis section (see Table II) is thenz
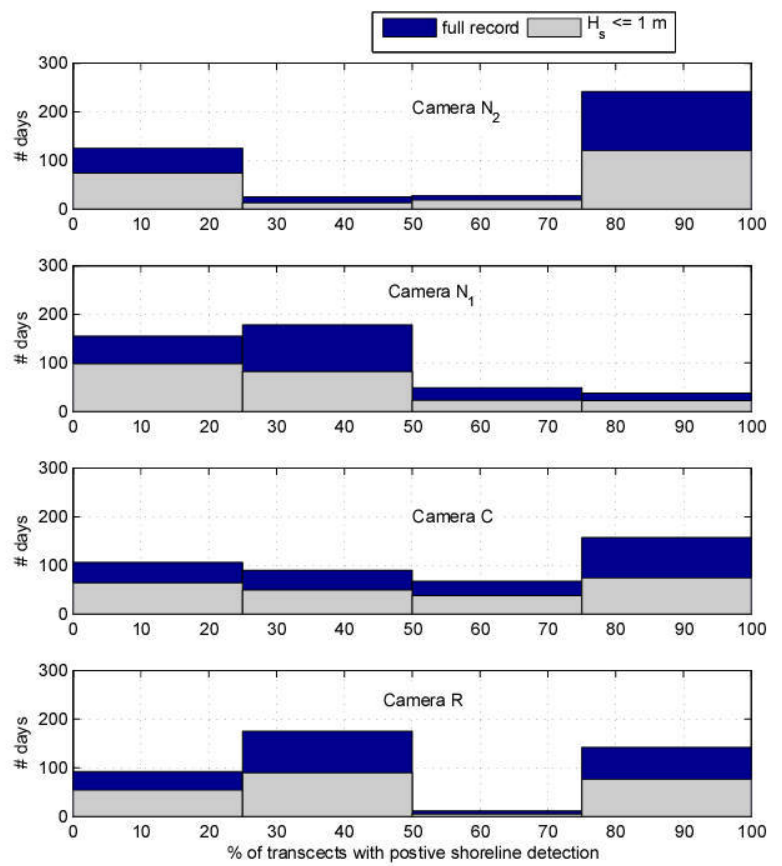

Fig. 7. Histogram of number of positive shoreline detections for each camera view of the Northern Beaches. Solid blue bars are based on full (420 day) record, while grey bars include only days where $H_{s} \leq 1 \mathrm{~m}$ (226 days). An image must return greater than $50 \%$ coverage (identified by $x$-axis) to be used to estimate a daily shoreline position.

calculated as well as weekly, and a 5-week running mean beach width.

While it is impractical to regularly survey the entire coast, a representative set of lines has been chosen for more frequent surveying. Two of these profiles fall within the regions monitored by the CoastalCOMS camera systems. ETA 32 at Palm Beach is located in the Camera $L_{2}$ field of view and ETA 67 is located within Camera $C$ of the Northern Beaches (Fig. 1). During the monitoring period presented here ETA 32 was surveyed on June 2, 2009 and again on April 29, 2010 as part of a 2D survey of Palm Beach. ETA 67 was surveyed on June 2, 2009 and May 21, 2010.

For Palm Beach, the June 2, 2009 CoastalCOMS derived shoreline was not recorded for Camera $L_{2}$. However, shoreline data was available \pm 2 days of the survey. Comparisons between the two indicated the CoastalCOMS derived shoreline had a $28.5 \mathrm{~m}$ shoreward bias. Comparison of the CoastalCOMS derived shoreline over the area covered by the April 2010 2D survey also had a shoreward mean bias of 17.5 $\mathrm{m}$. Between these two surveys, CoastalCOMS installed new cameras (April 2010) with new calibration parameters and may account for the decrease in bias seen in the second comparison. For the Northern Beaches, the CoastalCOMS shoreline data had a shoreward bias of $48 \mathrm{~m}$ for the June 2, 2009 survey and $36 \mathrm{~m}$ for the May 21, 2010 survey. However, the CoastalCOMS shoreline dips shoreward at the intersection of the ETA 67 transect in each case. Comparing an alongshore averaged section of beach width reduced the bias to 32 and $24 \mathrm{~m}$, respectively for the two surveys. The decrease 
TABLE II

SUMMARY OF CAMERA STATISTICS. NUMBER OF DAYS KEPT REFERS TO NUMBER OF DAYS WHERE MORE THAN $50 \%$ SHORELINE DETECTIONS WERE FOUND FOR THAT CAMERA VIEW (MAX. NUMBER OF DAYS IS 420). BRACKETED VALUES INDICATE THOSE WHERE $H_{S} \leq 1 \mathrm{M}$ AS WELL (MAX. NUMBER OF DAYS WITH $H_{s} \leq 1$ IS 266).

\begin{tabular}{ccccccc}
\hline Camera & $\begin{array}{c}\# \\
\text { transects }\end{array}$ & $\begin{array}{c}\text { Alongshore } \\
\text { coverage }(\mathrm{m})\end{array}$ & $\begin{array}{c}\text { Average alongshore } \\
\text { transect spacing }(\mathrm{m})\end{array}$ & $\begin{array}{c}\text { Average pixel } \\
\text { resolution }(\mathrm{m} / \mathrm{pixel})\end{array}$ & $\begin{array}{c}\text { \# days kept } \\
\left(H_{s} \leq 1 \mathrm{~m}\right)\end{array}$ \\
\hline \multirow{3}{*}{ Northern } & $R$ & 13 & $-1200<y<-450$ & 62.5 & 0.80 & $326(171)$ \\
Beaches & $N_{1}$ & 6 & $-400<y<-150$ & 50 & 0.34 & $280(141)$ \\
& $N_{2}$ & 9 & $750<y<1200$ & 75 & 0.46 & $236(109)$ \\
& $F$ & 11 & $-650<y<-150$ & 50 & 0.40 & $270(138)$ \\
\hline \multirow{5}{*}{ Palm } & $C \& \mathrm{R}$ & 5 & $-135<y<100$ & 59 & 0.51 & $319(169)$ \\
Beach & $L_{1}$ & 12 & $100<y<550$ & 41 & 0.75 & $209(118)$ \\
& $L_{2}$ & 6 & $594<y<1043$ & 57 & 0.46 & $274(157)$ \\
& $N_{1}$ & 9 & $1300<y<2100$ & 100 & 0.26 & $325(180)$ \\
& $N_{2}$ & 6 & $2200<y<3000$ & 160 & 0.44 & $276(152)$ \\
\end{tabular}
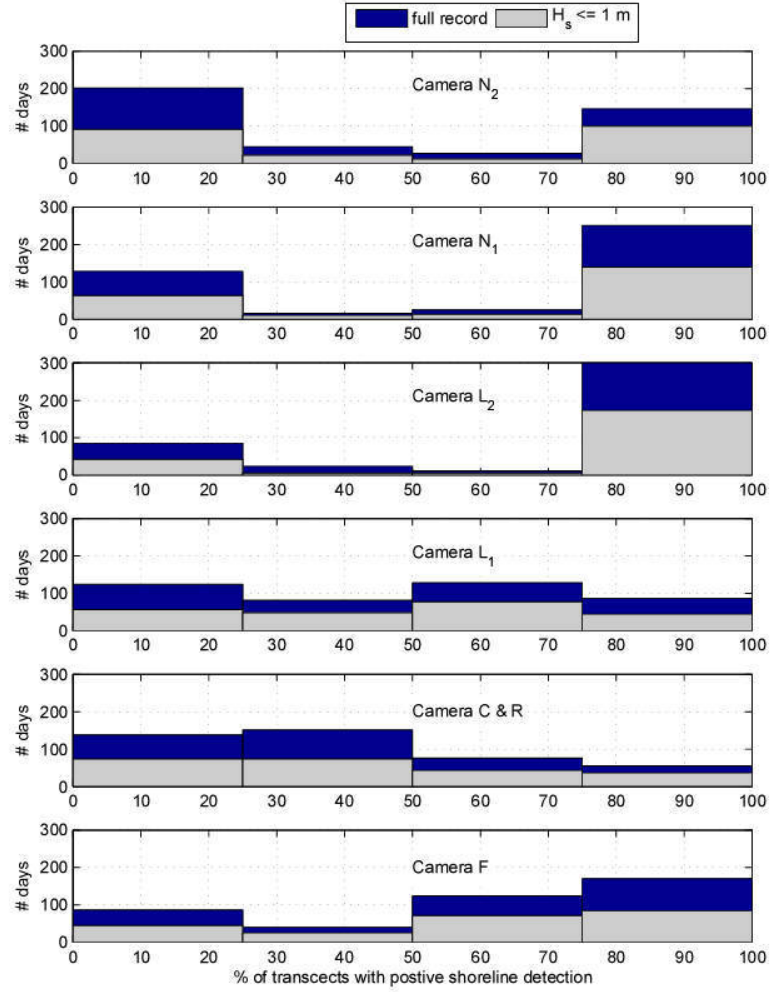

Fig. 8. Histogram of number of positive shoreline detections for each camera view of Palm Beach. Solid blue bars are based on full (420 day) record, while grey bars include only days where $H_{s} \leq 1 \mathrm{~m}$ (226 days). An image musts return greater than $50 \%$ coverage (identified by $x$-axis) to be used to estimate a daily shoreline position.

in bias between the two surveys may again be due to a newo camera system installed in December 2009 at this site. In adt instances, the measured shoreline bias exceeded the expected 2 error bands discussed in Section III-A. These may be due tos the limited number of GCP points that were used to solve fort the DLT coefficients. Current camera calibrations (Decembess
2010) contain 6 - 20 GCP points per camera and further constrain the linear least-squares problem. Additional sources of error that may also account for this bias include threshold values used to define the wet/dry line in the $H S V$ method, author bias in accepting/rejecting shoreline detections based on visual examination, accuracy of the hand-held GPS unit used to collect the GCP data points (and subsequently used to derive the DLT coefficients), as well as incorrect timing of image capture with respect to local mean sea level (maximum spring tide range is $\pm 1 \mathrm{~m}$ and equates to $\sim 30 \mathrm{~m}$ horizontal shoreline change if images were taken at high or low tide in error).

\section{B. Northern Beaches}

The mean beach width $\mu B W$ (relative to the A-line) for the Northern Beaches over this monitoring period was $61 \mathrm{~m}$ (alongshore standard deviation $\sigma_{y}$ of $7.0 \mathrm{~m}$ ), with a temporal variance $\sigma_{t}^{2}$ of $45 \mathrm{~m}^{2}\left(\sigma_{y}=0.5 \mathrm{~m}\right)$ (Fig. 5, Table III). Between May - June 2009, one major East Coast Low and one minor storm impacted the coastline and shorelines retreated an average of $-15 \mathrm{~m}\left(\sigma_{y}=1.8 \mathrm{~m}\right)$ (Fig. 9). During the milder winter and spring months (July - December 2009, Table I), beaches slowly accreted under prolonged mild wave conditions (mean rate of change $\mu \Delta B W=+0.69 \mathrm{~m} / \mathrm{week}, \sigma_{y}$ $=0.06 \mathrm{~m} /$ week) and beach widths were comparable to prestorm conditions (i.e. May 2009) by January $2010(\mu B W$ $=70 \mathrm{~m})($ Fig. 9). The Gold Coast region typically experiences its largest waves during the Australian summer and autumn(January - May) with storm activity such as East Coast Lows and Tropical Cyclones affecting the coast. Although no major storms occurred during January - June 2010, the Northern Beaches experienced shoreline recession and erosion of order $15 \mathrm{~m}$ due to seasonal increases in wave height (Table I) $\left(\mu \Delta B W=-0.45 \mathrm{~m} /\right.$ week, $\sigma_{y}=0.04 \mathrm{~m} /$ week $)$. Despite the seasonal shoreline recession, beach widths at the end of the analysis period (June 2010) were wider $(O 10 \mathrm{~m})$ than poststorm conditions recorded at the end of June 2009 (Fig. 9). Results are summarized in Tables III and IV. 
TABLE IV

SUMMARY OF MEAN RATES OF CHANGE $\mu \Delta B W$ (M/WEEK) IN ALONGSHORE-AVERAGED BEACH WIDTHS FOR EACH CAMERA VIEW AND WEIGHTED MEAN FOR EACH SITE.

\begin{tabular}{ccccc}
\hline Site & Camera ID & May - June 2009 & July - December 2009 & January - June 2010 \\
& $C$ & -1.76 & 0.93 & -1.01 \\
Northern & $R$ & -1.79 & 0.74 & -0.48 \\
Beaches & $N_{1}$ & -1.34 & 0.69 & -0.36 \\
& $N_{2}$ & -1.79 & 0.56 & -0.28 \\
& All & $\mathbf{- 1 . 7 0}\left(\sigma_{y}=\mathbf{0 . 2 1} \mathbf{~ m}\right)$ & $\mathbf{0 . 6 9}\left(\sigma_{y}=\mathbf{0 . 0 6} \mathbf{~ m}\right)$ & $\mathbf{- 0 . 4 5}\left(\sigma_{y}=\mathbf{0 . 0 4} \mathbf{~ m}\right)$ \\
\hline \multirow{5}{*}{ Palm } & $F$ & 0.54 & 1.11 & -1.53 \\
Beach & $C \& R$ & -0.66 & 0.73 & 0.81 \\
& $L_{1}$ & -3.81 & 1.33 & 2.08 \\
& $L_{2}$ & -3.58 & 1.02 & 0.84 \\
& $N_{1}$ & No data & 0.39 & 0.14 \\
& $N_{2}$ & No data & 0.22 & 0.37 \\
& All & $\mathbf{- 1 . 9 6}\left(\sigma_{y}=\mathbf{0 . 6 2} \mathbf{~ m}\right)$ & $\mathbf{0 . 7 1}\left(\sigma_{y}=\mathbf{0 . 0 6} \mathbf{~ m}\right)$ & $\mathbf{0 . 3 0}\left(\sigma_{y}=\mathbf{0 . 1 8} \mathbf{~ m}\right)$ \\
\hline
\end{tabular}

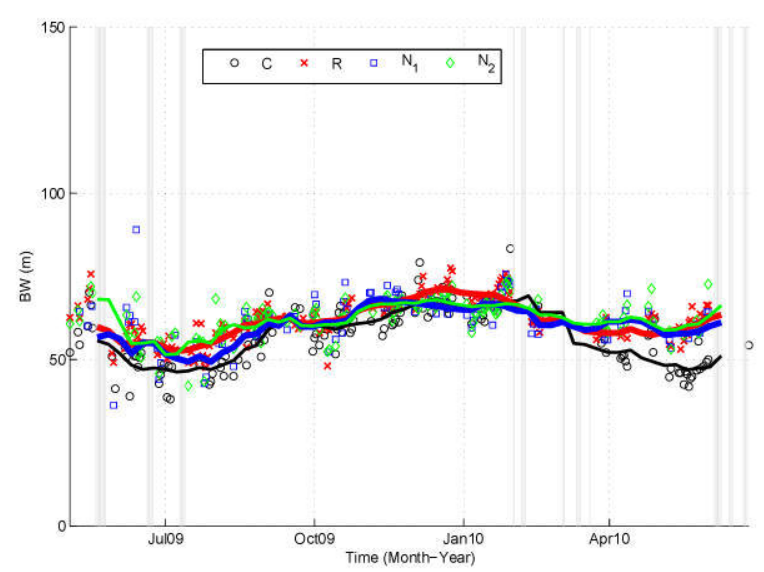

Fig. 9. Alongshore-averaged beach width estimates for the 4 cells at the Northern Beaches. Symbols represent daily alongshore-averaged beach width estimate and solid line is the 5 -week running mean shoreline. Vertical light grey bands represent periods when $H_{s}>2 \mathrm{~m}$.

TABLE III

ALONGSHORE-AVERAGED BEACH WIDTH STATISTICS FOR EACH CAMERA AND WEIGHTED ALONGSHORE MEAN VALUES FOR NORTHERN BEACHES.

\begin{tabular}{ccc}
\hline Camera ID & $\mu$ BW $(\mathrm{m})$ & $\sigma_{t}$ BW $(\mathrm{m})$ \\
\hline$R$ & 61 & 6.2 \\
$C$ & 56 & 8.2 \\
$N_{1}$ & 60 & 7.5 \\
$N_{2}$ & 62 & 6.2 \\
All & $\mathbf{6 1}\left(\sigma_{y}=\mathbf{7 . 0} \mathbf{~ m}\right)$ & $\mathbf{6 . 7}\left(\sigma_{y}=\mathbf{0 . 5} \mathbf{~ m}\right)$ \\
\hline
\end{tabular}

\section{Palm Beach}

Mean beach widths $\mu B W$ for Palm Beach over this mon $_{47}$ itoring period were $67 \mathrm{~m}\left(\sigma_{y}\right.$ of $\left.4.8 \mathrm{~m}\right)$, with a temporal variance $\sigma_{t}^{2}$ of $115 \mathrm{~m}^{2}\left(\sigma_{y}=0.8 \mathrm{~m}\right)\left(\right.$ Fig. 6 , Table V). Between ${ }^{55}$ May - June 2009, shorelines retreated an average of -17 mа $\left(\sigma_{y}=5.4 \mathrm{~m}\right)$ (Fig. 10). In some areas, the erosion was so severe that it exposed the boulder wall and necessitateds beach nourishment. Beach scraping to reprofile the beach ands

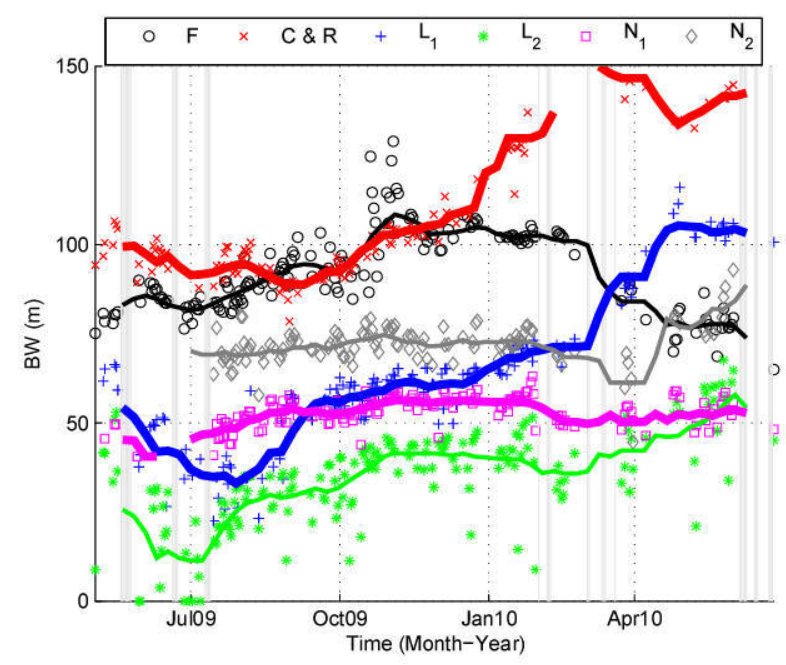

Fig. 10. Alongshore-averaged beach width estimates for the 6 cells at Palm Beach. Symbols represent daily alongshore-averaged beach width estimate and solid line is the 5-week running mean shoreline. Vertical light grey bands represent periods when $H_{s}>2 \mathrm{~m}$.

cover the boulder wall, as well as nourishment from southern Kirra Beach and dredging of the adjacent creek aided in beach recovery. From July through December 2009, beaches slowly accreted under prolonged mild wave conditions $(\mu=$ $+0.71 \mathrm{~m} /$ week, $\sigma_{y}=0.06 \mathrm{~m} /$ week). Over the latter half of the monitoring period (January - June 2010), Palm Beach continued to accrete on average ( $\mu=+0.3 \mathrm{~m} /$ week, $\sigma_{y}=0.18$ $\mathrm{m} /$ week), although considerable alongshore variability existed and some sections underwent erosion while others accreted (Fig. 10). Results are summarized in Tables IV and V.

\section{DISCUSSION}

\section{A. Intra-site Variability}

Beach width variability at the Northern Beaches was significantly correlated at the $99 \%$ level (Table VI) and showed very little intra-site variability (Fig. 9, Tables III and IV). Maximum correlation within the site was between cameras $R$ and $N_{1}$ 
TABLE V

ALONGSHORE-AVERAGED BEACH WIDTH STATISTICS FOR EACH CAMER A $^{14}$ VIEW AND WEIGHTED ALONGSHORE MEAN VALUES FOR PALM BEACH.

\begin{tabular}{ccc}
\hline Camera ID & $\mu \mathrm{BW}(\mathrm{m})$ & $\sigma_{t}$ BW $(\mathrm{m})$ \\
\hline$F$ & 91 & 11.6 \\
$C \& R$ & 109 & 19.9 \\
$L_{1}$ & 63 & 22.2 \\
$L_{2}$ & 35 & 13.2 \\
$N_{1}$ & 53 & 4.1 \\
$N_{2}$ & 72 & 5.7 \\
All & $\mathbf{6 7}\left(\sigma_{y}=\mathbf{4 . 8} \mathbf{~ m}\right)$ & $\mathbf{1 0 . 7 5}\left(\sigma_{y}=\mathbf{0 . 8} \mathbf{~ m}\right)$ \\
\hline
\end{tabular}

TABLE VI

Spatial Correlation $(R)$ ANAlysis For Northern BeACHES. AlL ARE SIGNIFICANT AT THE $99 \%$ LEVEL.

\begin{tabular}{c|cccc}
\hline Camera ID & $R$ & $C$ & $N_{1}$ & $N_{2}$ \\
\hline$R$ & 1 & 0.8735 & 0.9007 & 0.8518 \\
$C$ & - & 1 & 0.827 & 0.7613 \\
$N_{1}$ & - & - & 1 & 0.8496 \\
$N_{2}$ & - & - & - & 1 \\
\hline
\end{tabular}

(0.9), while minimum correlation was found between cameras $C$ and $N_{2}$. The long straight coast and minimal engineering ${ }^{57}$ this site gives an example of shoreline variability under natural conditions. The Argus monitoring prior to 2009 identified ${ }^{539}$ similar seasonal trend of erosion and recovery consistent with our analysis and with the monthly mean wave buoy data [445. In 2004 the annual cycle was interrupted by a single large event in October followed by atypical net accretion in the first half of the 2005 calendar year with a return to the typicál cyclic seasonal behaviour in 2006.

Palm Beach exhibits a distinctively different beach width variability (Table V, Fig. 6). Unlike the Northern Beaches ${ }^{6}$ that are signficantly correlated at the $99 \%$ level, Palm Beacha is divided into several compartments that are correlated ats varying significance levels (Table VII). The beach directlyy adjacent to the creek (Camera $F$ ) is one of the widest sectionso of beach and is carefully monitored to avoid breaching of the creek at the landward edge of the training wall. Unlike the resiz of Palm Beach, the section monitored by Camera $F$ underwents significant erosion between January and June 2010, whike the downdrift sections (Cameras $C \& R$ and $L_{1}$ ) experienceds accretion. The beach sections monitored by Cameras $C \& R_{56}$ $L_{1}$, and $N_{2}$ are negatively correlated with Camera $F$ (Tabber VII) and account for the observed beach rotation (Fig. 10) du to changes in the mean angle of incidence (Table I). The tw\$9 groynes trap sand and modulate beach response (Camera $N_{560}$ Fig. 10). The section of beach between the groynes (Camerat $\left.N_{1}\right)$ showed the least amount of temporal variability $\left(\sigma_{t}=4_{5} k_{2}\right.$ $\mathrm{m})$, while Camera $L_{1}$ had the highest amount of variabilitis 3 $\left(\sigma_{t}=22.2 \mathrm{~m}\right)$. This section of beach is some of the most 4 vulnerable and due to the frequent exposure of the boulder wadds receives annual nourishment. The impact of this nourishmento resulted in a local seaward accretion of the shoreline betweesa August and October 2009 by approximately $20 \mathrm{~m}$. Minors nourishment in July 2009 was also placed along the exposed boulder wall in Camera $L_{2}$. During this period mean wave direction was from the north (Table I) and lagged spatial response of the nourishments is observed in the southern cameras (Fig. 10). Along with nourishment activities, beach rotation within the cell defined between Cameras $F$ and $L_{2}$ (Table VII) accounts for the high temporal variance observed (Table V). Similar patterns of beach erosion (accretion) at the southern end of Palm Beach and accretion (erosion) adjacent to the 11th Ave. groyne and at the northern end during the first (second) half of the year were also observed during the Argus monitoring period [45]. However, large wave events (similar to that of the May 2009 event) cause the entire beach to erode and are typically followed by accretion of the entire beach during mild wave conditions.

\section{B. Inter-site Variability}

Significant inter-site variability exists between the Northern Beaches and Palm Beach. This is primarily due to the amount of ongoing coastal engineering works, but local wave climate can also have a large impact. Comparison of measured and modeled wave conditions from the Northern Beaches and Palm Beach (Table I) indicate Palm Beach experiences lower and more northerly mean wave climates than the more exposed Northern Beaches. While the long straight beach at the Northern Beaches uniformly modulate with changes in wave height (Fig. 9 and Tables IV and VI), the more pocket-like beach design of Palm Beach does not and is more sensitive to changes in mean wave direction (Fig. 10 and Tables IV and VII). The impact of large storms (specifically those from the east where both beaches are exposed) is similar at both beaches, with large erosion occurring followed by periods of accretion.

\section{Relationship to Wave Conditions}

Comparison of mean wave statistics from the Gold Coast buoy and the beach width of the Northern Beaches reveals the expected trends of higher energy conditions resulting in shoreline erosion and milder conditions encouraging accretion (Table I vs. Table IV). A cross-correlation analysis of the 5week running averaged beach width $B W$ for each camera view vs. significant wave height $H_{s}$, as well as beach width vs. dimensionless fall velocity $\Omega=H_{s} / T_{p} w$, where $w$ is the sediment fall velocity are summarized in Table VIII. For the Northern Beaches, significant and negative cross-correlations at time lags of $0-14$ weeks (for $H_{s}$ ) and $4-21$ weeks (for $\Omega$ ) vs. $B W$ are observed. An example from Camera $R$ (Northern Beaches) is given in Figure 11. The results indicate increases in wave height are followed by decreases in beach width, while beach response to changes in the dimensionless fall velocity are slightly lagged. For the long, straight, exposed Northern Beaches, the relationship between beach width and dimensionless fall velocity indicate that more dissipative conditions (higher $\Omega$ ) result in decreased beach width for this site. Similar results were shown by Davidson and Turner [31] that presented significant negative correlations between shoreline position and dimensionless fall velocity for 
TABLE VII

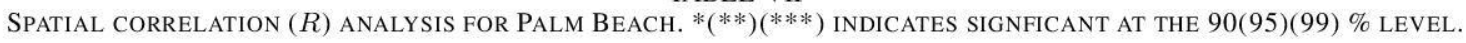

\begin{tabular}{c|cccccc}
\hline Camera ID & $F$ & $C \& R$ & $L_{1}$ & $L_{2}$ & $N_{1}$ & $N_{2}$ \\
\hline$F$ & 1 & $-0.2532 *$ & $-0.3049 * *$ & 0.0646 & $0.5770 * * *$ & -0.2150 \\
$C \& R$ & - & 1 & $0.7359 * * *$ & $0.8978^{* * * *}$ & 0.1882 & 0.1146 \\
$L_{1}$ & - & - & 1 & $0.543 * * *$ & $0.2551^{*}$ & $0.3628^{* *}$ \\
$L_{2}$ & - & - & - & 1 & $0.6462 * * *$ & $0.4923^{* * *}$ \\
$N_{1}$ & - & - & - & - & 1 & $0.3233^{* *}$ \\
$N_{2}$ & - & - & - & - & - & 1 \\
\hline
\end{tabular}

lags of 0 to 20 weeks. The positive lags between 24 - 38 weeks (Fig. 11) are indicative of the seasonal cycle in wave climate.

Cross-correlation between SWAN output wave conditions at Palm Beach and beach width statistics do not show similar patterns between changes in wave height and beach width. Camera $\mathrm{N}_{2}$ was significantly negatively correlated with $H_{s}$ for lags less than 6 weeks and $\Omega$ for lags less than 7 weeks. Cameras $N_{1}$ and $F$ had similar results to the Northern Beaches with signficant negative cross-correlations between $B W$ and $H_{s}$ for time lags 1-14 weeks (5 - 20 weeks for Camera $F$ ) and 5 - 19 (7 - 23 for Camera $F)$ weeks for $\Omega$. The central beach cameras $\left(L_{1}\right.$ and $C \& R$ ) had significant positive crosscorrelations between beach width and $H_{s}(2-10$ weeks for $C \& R$ and $6-16$ weeks for $\left.L_{1}\right)$ and $\Omega(2-16$ weeks for $C \& R$ and 6 - 23 weeks for $L_{1}$ ). The opposite sign of the cross-correlation for Cameras $L_{1}, C \& R$ and $F$ again suggest wave angle and beach rotation may be the dominant forcing term for beach width response at this beach. Camera $L_{2}$ had significant positive correlations for $H_{s}$ at 11 weeks and for $\Omega$ at lags $11-27$ weeks. For the alongshore-averaged $B W$, significant correlations were only found at long lags. Table VIII summarizes the maximum significant correlation and the corresponding lag for each of the camera views.

\section{Beach Volumes vs. Shorelines to Determine Beach Vulner- ability}

Beach profiles measured using traditional in situ survey 4 methods can not economically provide the spatial or temporals coverage that is now available with remote sensing techniquesto However, surveys do provide periodic, but valuable volumetries data that informs coastal management decisions. While shorets lines may recover rapidly after a storm as eroded sand movese onshore, the rebuilding of the upper beach (and dune) that actso as the principal line of defense against inundation recovers at much longer time scales. Here we compare the volumetribez changes and shorelines measured from profile survey data ats the two sites. Using the $1 \mathrm{D}$ continuity equation (1) that relateses changes in depth $h(\mathrm{~m})$ to cross-shore $x$ gradients in sediments transport $Q_{x}\left(\mathrm{~m}^{2} / \mathrm{s}\right)$ via a sediment packing factor $\mu$ we capa estimate volumetric changes between two adjacent surveys. ${ }_{627}$

$$
\frac{d h}{d t}(x)=\frac{1}{\mu} \frac{d Q_{x}}{d x}(x)
$$

ETA 67 experienced a shoreline retreat of $13 \mathrm{~m}$ between the December 15, 2008 and the June 2, 2009 survey (Fig. 12ok2

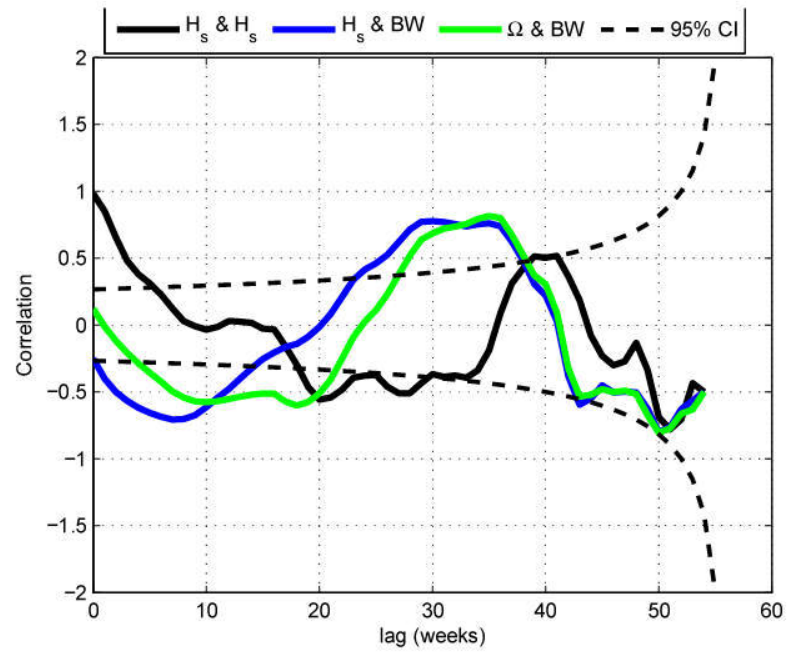

Fig. 11. Auto-correlation functions for signficant wave height $H_{s}$ (solid black line) and cross-correlation functions for beach width $B W$ (as measured at Northern Beaches, camera $R$ ) and significant wave height $H_{s}$ (blue line), as well as dimensionless fall velocity $\Omega=H_{s} / T_{p} w$ (green line) as measured from Gold Coast buoy. Dashed line indicate the $95 \%$ significance level. Positive lags indicate forcing leads beach width response.

From (1) $419 \mathrm{~m}^{3} / \mathrm{m}$ was eroded from the upper profile (out to $x=400 \mathrm{~m}$ ), of which $71 \mathrm{~m}^{3} / \mathrm{m}$ was from the dry beach area defined by Australian Height Datum $A H D \geq 0$. The majority of this sand $\left(401 \mathrm{~m}^{3} / \mathrm{m}\right)$ was deposited in an offshore sand bar. The net change for ETA 67 for the six month period was $-18 \mathrm{~m}^{3} / \mathrm{m}$, suggesting longshore gradients in transport are minimal at this site. By the next survey (May 21, 2010) the shoreline had advanced by $15 \mathrm{~m}$, returning to within $2 \mathrm{~m}$ of the December 2008 shoreline. However, the volumetric analysis indicates the upper beach has not recovered, with dry beach volumes $(A H D \geq 0), \sim 5 \mathrm{~m}^{3} / \mathrm{m}$ less than the June 2009 survey and $\sim 76 \mathrm{~m}^{3} / \mathrm{m}$ less than the December 2008 survey.

For Palm Beach, differences between the April and June 2009 ETA 32 surveys reveal a shoreline retreat of $22 \mathrm{~m}$. From (1), the total eroded volume was calculated to be $496 \mathrm{~m}^{3} / \mathrm{m}$, with a reduction in the dry beach profile volume of $59 \mathrm{~m}^{3} / \mathrm{m}$ and only $17 \mathrm{~m}^{3} / \mathrm{m}$ of sand remaining in front of the boulder wall (Fig. 13). Unlike the Northern Beaches who had very little loss of sand within the profile, only half of the eroded volume $\left(258 \mathrm{~m}^{3} / \mathrm{m}\right)$ was deposited offshore. Thus, the net change in profile volume due to the May 2009 event was $-238 \mathrm{~m}^{3} / \mathrm{m}$ and attributed to gradients in longshore transport. Between July and October 2009 Palm Beach received roughly 70,000 
TABLE VIII

LAGGED CROSS-CORRELATION ANALYSIS RESULTS FOR EACH CAMERA VIEW. RESULTS GIVEN ARE FOR MAXIMUM SIGNIFICANT LAG (WEEKS) WITH CORRELATION VALUE, $R$.

\begin{tabular}{cccccc}
\hline Site & Camera ID & \multicolumn{2}{c}{$B W \& H_{s}$} & \multicolumn{2}{c}{$B W \& \Omega$} \\
& & $R$ & lag (weeks) & $R$ & lag (weeks) \\
\hline \multirow{5}{*}{ Northern } & $C$ & -0.79 & 9 & -0.76 & 12 \\
Beaches & $R$ & -0.71 & 7 & -0.6 & 18 \\
& $N_{1}$ & -0.70 & 12 & -0.71 & 12 \\
& $N_{2}$ & -0.65 & 8 & -0.64 & 19 \\
& All & $\mathbf{- 0 . 7 3}$ & $\mathbf{8}$ & $\mathbf{- 0 . 6 6}$ & $\mathbf{1 2}$ \\
\hline \multirow{5}{*}{ Palm } & $F$ & -0.77 & 12 & -0.82 & 16 \\
Beach & $C \& R$ & 0.49 & 6 & 0.60 & 8 \\
& $L_{1}$ & 0.45 & 11 & 0.62 & 16 \\
& $L_{2}$ & 0.33 & 11 & 0.61 & 24 \\
& $N_{1}$ & -0.62 & 9 & -0.66 & 14 \\
& $N_{2}$ & -0.59 & 2 & -0.46 & 4 \\
& All & $\mathbf{- 0 . 8 8}$ & $\mathbf{4 4}$ & $\mathbf{0 . 5 0}$ & $\mathbf{2 3}$ \\
\hline
\end{tabular}

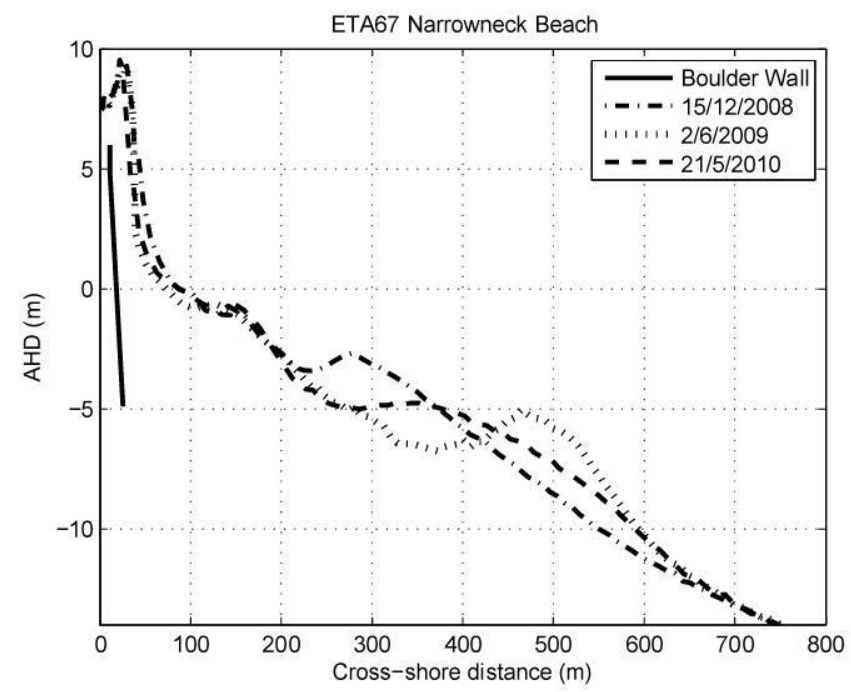

Fig. 12. Beach profiles surveyed at ETA 67, Narrowneck Beach. Solid line indicates buried boulder wall (A-line). Pre-storm survey from December 15, 2008 (Dash-dot), post-storm survey from June 2, 2009 (dot) and final survey from May 21, 2010 (dash).

$\mathrm{m}^{3}$ of sand on the upper beach profile. By April 29, 2010 the shoreline had advanced seaward by $38 \mathrm{~m}$ and the dry beach volume was $145 \mathrm{~m}^{3} / \mathrm{m}$, both exceeding the pre-storm (April 2009) survey values.

It is apparent from the comparison of the CoastalCOMS shoreline data and survey data that shorelines can recover from major storms at a reasonably rapid rate under favourable wave conditions. However, the dry beach volumes measured from the survey data show that the upper beach can take substarass tially longer to recover under natural conditions (i.e. Northeras Beaches). This suggests that monitoring just the shorelines position may over-estimate beach resiliency. However, thes alongshore extent of morphological variability, especially ato the highly engineered Palm Beach site, is not revealed by reps7 resentative profile survey data alone. This highlights the needs

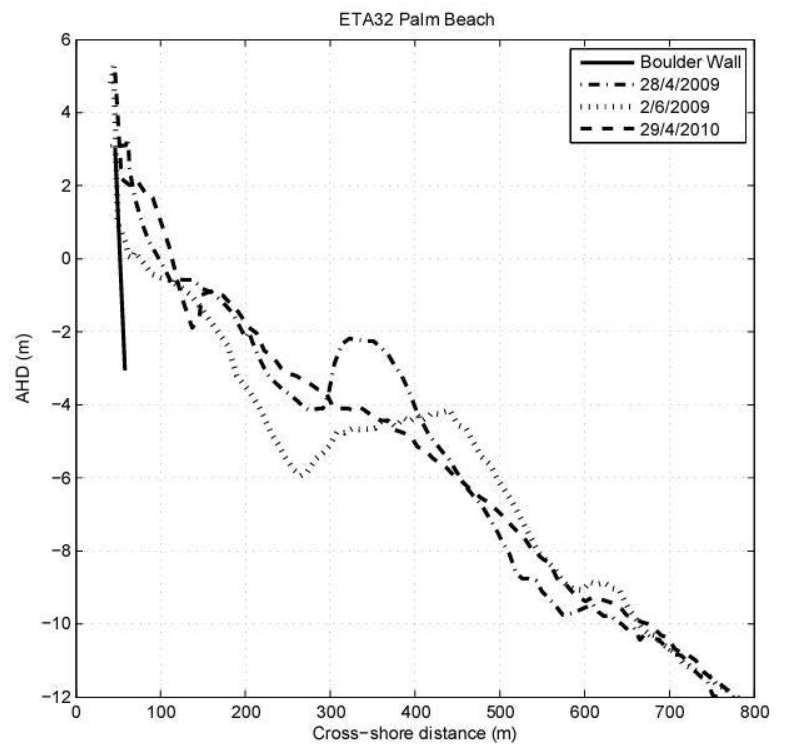

Fig. 13. Beach profiles surveyed at ETA 32, Palm Beach. Solid line indicates buried boulder wall (A-line). Pre-storm survey from April 28, 2009 (Dashdot), post-storm survey from June 2, 2009 (dot) and final survey from April 29, 2010 (dash).

for the mutually beneficial collection of survey and remotely sensed data for supporting coastal management actions.

\section{CONCLUSIONS}

Coastal monitoring through the use of video camera technology provides a low-cost, nearly continuous data set to which coastal managers can make important decisions about beach vulnerability and nourishment activities over large areas of coastline without the need for ongoing costly surveys. A new camera system has been tested to determine its applicability and accuracy of video-derived shorelines to aid in coastal monitoring of two 4-km sections of coastline in Gold 
Coast, Australia. A 14-month data set, covering one major 4 storm, a recovery period, and an annual cycle was used. The CoastalCOMS derived daily shorelines were available $\sim 64 \%_{06}^{5}$ of the time and were used to determine weekly and 5-week ${ }^{7}$ running average beach widths. Comparison against in situi surveys showed the video-derived shorelines had a shoreward bias of $23 \mathrm{~m}$ at Palm Beach and $28 \mathrm{~m}$ at the Northern Beachese, exceeding the expected error bands of previous video-derive ${ }_{723}^{72}$ shoreline estimates.

Camera-derived shorelines highlighted the beaches erosiơn and subsequent recovery from the May 2009 storm event, $t_{27}^{726}$ as well as natural cycles in beach width due to seasonads wave height and direction variability. The more expose ${ }^{9}$ Northern Beaches displayed very little intra-site variability/31 with significant positive spatial correlations between differend sections of the beach. Beach width was significantly negativet ${ }^{3}$ correlated with wave height and dimensionless fall velocity $y_{35}^{734}$ indicating increases in wave height are followed by reductions 6 in beach width. The more sheltered Palm Beach, which is als ${ }^{7}{ }^{7}$ highly engineered, can be split into distinct alongshore $\sec ^{738}$ tions. Significant negative spatial correlations between sections were representative of beach oscillations observed on pockęt beaches and attributed to changes in mean wave direction $\eta_{43}^{72}$ Both positive and negative significant lagged cross-correlation $\$_{4}$ of beach width and wave height were seen at Palm Beach,5 indicating the large intra-site variability at this site, as we $71_{74}^{6}$ as suggesting that Palm Beach is more sensitive to waves angle (compared to wave height) in determining the temporăł ${ }^{9}$ evolution of beach width.

750
751

Comparison with yearly beach surveys suggest that botha methods of beach analysis are important to understanding the long term health of the beach. The surveys were not ab $\int_{55}^{54}$ to capture the short-term temporal shoreline variability, the intra-site variability, or links to wave properties. However, they highlighted the fact that despite post-storm shoreline ${ }_{759}^{758}$ accretion, dry beach volumes (and thus dune health) wereo still reduced compared to pre-storm conditions where $n^{7} \oint^{1}$ nourishment activities had occurred.

With an ever-expanding network of surf cameras along out coastlines, this technology provides a number of tertiary ben ${ }^{365}$ efits to local government and researchers. The CoastalCOM $\mathrm{M}_{87}^{766}$ system used here demonstrates the applicability of single hights resolution camera installations to provide shoreline estimates within a reasonable level of accuracy for coastal management needs.

\section{ACKNOWLEDGMENT}

The authors would like to thank M. Elliot-Smith and C.8 Lane from CoastalCOMS for providing the shoreline dat9 and information on camera set-up and calibration. Wave data was provided by Department of Environment and Resource Management (DERM) Queensland and the Gold Coast Citi $\mathbb{1}_{4}^{783}$ Council. Beach surveys were provided by Gold Coast City 5 Council Engineering Services. The authors extend their sincer ${ }^{86}$ appreciation to the 3 reviewers who provided comments that improved the quality of this paper.

\section{REFERENCES}

[1] D. Strauss, R. Tomlinson, and S. Hunt, "Profile response and dispersion of beach nourishment: Gold Coast, Australia," Journal of Coastal Research, vol. SI 56 (Proceedings of the 10th International Coastal Symposium), pp. 133-137., 2009.

[2] K. Holland, R. Holman, T. Lippmann, J. Stanley, and N. Plant, "Practical use of video imagery in nearshore oceanographic field studies," IEEE Journal of Ocean Engineering, vol. 22, no. 1, 1997.

[3] R. Holman, J. Stanley, and H. Özkan Haller, "Applying video sensor networks to nearshore environmental monitoring," IEEE Pervasive Computing, vol. 2, no. 4, pp. 14-21, 2003.

[4] I. L. Turner, S. G. J. Aarninkhof, and R. A. Holman, "Coastal imaging applications and research in Australia," Journal of Coastal Research, vol. 22, no. 1, pp. 37-48, 2006.

[5] R. A. Holman and J. Stanley, "The history and technical capabilities of Argus," Coastal Engineering, vol. 54, pp. 447-491, 2007.

[6] H. Stockdon and R. Holman, "Estimation of wave phase speed and nearshore bathymetry from video imagery," Journal of Geophysical Research, vol. 105, no. C9, pp. 22,015-22,033, 2000.

[7] T. K. Holland, "Application of the linear dispersion relation with respect to depth inversion and remotely sensed imagery," IEEE Transactions on Geoscience and Remote Sensing, vol. 39, no. 9, pp. 2060-2072, 2001.

[8] S. G. J. Aarninkhof, B. G. Ruessink, and J. A. Roelvink, "Nearshore subtidal bathymetry from time exposure images," Journal of Geophysical Research, vol. 110, p. C06011, 2005.

[9] K. D. Splinter and R. A. Holman, "Bathymetry estimation from singleframe images of nearshore waves," IEEE Transactions on Geoscience and Remote Sensing, vol. 47, no. 9, pp. 3151-3160, 2009.

[10] T. C. Lippmann and R. A. Holman, "Quantification of sand bar morphology: A video technique based on wave dissipation," Journal of Geophysical Research, vol. 94, no. C1, pp. 995-1011, 1989.

[11] M. Browne, D. Strauss, R. Tomlinson, and M. Blumenstein, "Objective beach-state classification from optical sensing of cross-shore dissipation profiles," IEEE Transactions on Geoscience and Remote Sensing, vol. 44, no. 11, pp. 3418-3426, 2006.

[12] C. Armaroli and P. Ciavola, "Dynamics of a nearshore bar system in the northern Adriatic: A video-based morphological classification," Geomorphology, 2010.

[13] T. Lippmann and R. Holman, "The spatial and temporal variability of sand bar morphology," Journal of Geophysical Research, vol. 95, no. C7, pp. 11,575-11,590, 1990.

[14] I. van Enckevort, B. Ruessink, G. Coco, K. Suzuki, I. Turner, N. Plant, and R. A. Holman, "Observations of nearshore crescentic sandbars," Journal of Geophysical Research, vol. 109, no. C6, 2004.

[15] F. Ribas, E. Ojeda, T. D. Price, and J. Guillén, "Assessing the suitability of video imaging for studying the dynamics of nearshore sandbars in tidelss beaches," IEEE Transactions on Geoscience and Remote Sensing, vol. 48, no. 6, pp. 2482-2497, 2010.

[16] K. D. Splinter, R. Holman, and N. Plant, "A behavior-oriented dynamic model for sand bar migration and 2DH evolution," Journal of Geophysical Research, in press.

[17] R. A. Holman and C. C. Chickadel, "Optical remote sensing estimates of the incident wave angle field during NCEX," in 29th International Conference on Coastal Engineering. Lisbon, Portugal: ASCE, 2004.

[18] N. Plant, K. T. Holland, and M. Haller, "Ocean wavenumber estimation from wave-resolving time series imagery," IEEE Transactions on Geoscience and Remote Sensing, vol. 46, pp. 2644-2658, 2008.

[19] C. Lane, Y. Gal, M. Browne, A. Short, D. Strauss, R. Tomlinson, K. Jackson, C. Tan, and M. Blumenstein, "A new system for breakzone location and the measurement of breaking wave heights and periods," in Proceedings of the 2010 IEEE International Geoscience and Remote Sensing Symposium, Honolulu, USA, 2010.

[20] I. Turner, V. Leyden, G. Symonds, J. Mcgrath, A. Jackson, T. Jancar, S. Aarninkhof, and I. Elshoff, "Comparison of observed and predicted coastline changes at the Gold Coast artificial (surfing) reef," in Proceedings of the 27th International Conference on Coastal Engineering. Sydney, Australia: ASCE, 2000.

[21] I. L. Turner, "Discriminating modes of shoreline response to offshoredetached structures," Journal of Waterway, Port, Coastal and Ocean Engineering, vol. 132, no. 3, pp. 189-191, May/June 2006.

[22] R. Holman, A. J. Sallenger., T. Lippmann, and J. Haines, "The application of video image processing to the study of nearshore processes," Oceanography, vol. 6, no. 3, pp. 78-85, 1993.

[23] N. Plant, S. Aarninkhof, I. Turner, and K. Kingston, "The performance of shoreline detection models applied to video imagery," Journal of Coastal Research, vol. 23, no. 3, pp. 658-670, 2007. 
[24] N. Plant and R. Holman, "Intertidal beach profile estimation using videer images," Marine Geology, vol. 140, pp. 1-24, 1997.

868

[25] P. S. Alexander and R. A. Holman, "Quantitative analysis of nearshoøe9 morphological variability based on video imaging," Marine Geology, vol. 208, no. 1, pp. 101-111, 2004.

[26] S. G. J. Aarninkhof, I. L. Turner, T. D. T. Dronkers, M. Caljouw, and L. Nipius, "A video technique for mapping intertidal beach bathymetry," Coastal Engineering, vol. 49, pp. 275-289, 2003.

[27] K. S. Kingston, "Application of complex adaptive systems, approaches to coastal systems," Ph.D. Thesis, University of Plymouth, 2003.

[28] S. Aarninkhof and R. Holman, "Monitoring the nearshore with video," Backscatter, vol. 10, no. 2, pp. 8-11, 1999.

[29] I. L. Turner, S. G. J. Aarninkhof, T. D. T. Dronkers, and J. McGrat\$70 "CZM applications of Argus coastal imaging at the Gold Coast, Australia," Journal of Coastal Research, vol. 20, pp. 739-752, 2004.

[30] Y. I. Abdel-Aziz and H. M. Karara, "Direct linear transformatio $87^{3}$ from comparator coordinates into object space coordinates in close 874 range photogrammetry," in Proceedings of the Symposium on Close 875 Range Photogrammetry. Falls Church, VA: American Society $87^{6}$ Photogrammetry, 1971 , pp. 1-18.

[31] M. A. Davidson and I. L. Turner, "A behavioral template beach pro 878 file model for predicting seasonal to interannual shoreline evolution, Journal of Geophysical Research, vol. 114, p. F01020, 2009.

[32] L. Boak, J. McGrath, and L. A. Jackson, "IENCE - a case study - TRę1 Northern Gold Coast Beach Protection Strategy," in Proceedings of the्2 27th International Conference on Coastal Engineering, vol. 4, 2000, p. 37103717.

[33] A. Jackson, R. Tomlinson, J. McGrath, and I. L. Turner, "Monitoring of a multifunctional submerged geotextile reef breakwater," in Proceedings of the 28th International Conference on Coastal Engineering, vol. 2, 2002, p. 19231935.

[34] D. Patterson, "Sand transport and shoreline evolution, northern Gold Coast, Australia," Journal of Coastal Research, vol. SI 50 (Proceedings of the 9th International Coastal Symposium), pp. 147-151, 2007.

[35] M. Hemer, J. Church, and J. Hunter, "Waves and climate on thes Australian coast," Journal of Coastal Research, vol. SI 50 (Proceedings5 of the 9th International Coastal Symposium), pp. 432-437, 2007.

[36] M. D. Harley, I. L. Turner, A. D. Short, and R. Ranasinghe, "Interannusiz variability and controls of the Sydney wave climate," Internationsd8 Journal of Climatology, vol. 30, pp. 1322-1335, 2010.

[37] Q. Government, "Queensland wave climate summary for season 20030 - 2004," Coastal Services, data report 2005.1, 2005. [Online]. Availablosi http://www.derm.qld.gov.au/services_resources/item_details.php?item_dids=

[38] D. Strauss, A. Deshoulieres, R. Tomlinson, and C. Lane, "Near-shosses wave condition forecasts for the Southeast Queensland region,"44 in Inaugural Queensland Coastal Conference 2007, 17th 19th September 2007, Bundaberg, Qld, 2007. [Online]. Available: http://www.qldcoastalconference.org.au/images/upload_images/Strauss_Darrellv2.pdf

[39] K. D. Splinter, A. Golshani, G. Stuart, and R. Tomlinson, "Spatial and temporal variability of longshore transport along Gold Coast, Australia," in 32nd International Conference on Coastal Engineering. Shanghai, China: ASCE, 2010.

[40] K. D. Splinter and A. Golshani, "Development of a wave classification scheme to examine climate variability and nearshore response," in Proceedings of the Australian Wind Waves Research Science Symposium, 19-20 May 2010, Gold Coast, Queensland, Australia, K. A. Day., Ed., no. CAWCR Technical Report No. 029, 2010.

[41] D. Strauss, H. Mirferendesk, and R. Tomlinson, "Comparison 898 of two wave models for Gold Coast, Australia," Journal of Coastal Research, vol. SI 50 (Proceedings of the 9th International Coastal Symposium), pp. 312-316, 2007. [Online]. Available: http://www.griffith.edu.au/conference/ics2007/pdf/ICS061.pdf

[42] E. H. Boak and I. L. Turner, "Shoreline definition and detection: ${ }^{9}{ }^{3}$ review," Journal of Coastal Research, vol. 21, no. 4, pp. 688-703, 2005.

[43] J. S. Lee and I. Jurkevich, "Coastline detection and tracing in SAR" images." IEEE Transactions on Geoscience and Remote Sensing, vol. 28,207 pp. $662-668,1990$.

[44] M. Blacka, D. Anderson, and L. Mallen Lopez, "Analysis 908 shoreline variability, seasonality and erosion / accretion trends: February 2008 - July 2008. report 18: Northern Gold Coast coastal imaging system." Water Research Laboratory, University of New South Wales., Tech. Rep. WRL Technical Report 2008/27, 2008. [Online], Available: http://ci.wrl.unsw.edu.au/analysis/goldcst/Reports/WRL-TR2008-27.pdf

[45] - "Analysis of shoreline variability and erosion/accretion trends: June 2008 - October 2008. report 9 - Palm Beach coastal imaging system." Water Research Laboratory, University of New South
Wales., Tech. Rep. WRL Technical Report 2008/32, 2008. [Online]. Available: http://ci.wrl.unsw.edu.au/analysis/palmqld/Reports/WRL-TR2008-32.pdf

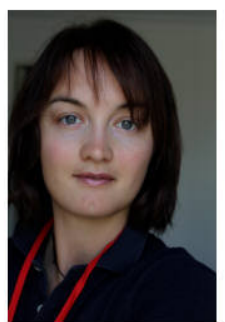

Kristen D. Splinter received the B.Sc. Eng.(Hons) degree in civil engineering from Queen's University, Kingston, ON, Canada in 2002, the M.S. degree in coastal and oceanographic engineering from the University of Florida, Gainesville, FL in 2004, and the Ph.D. degree in geological oceanography with certificate in marine resource management from Oregon State University, Corvallis, OR in 2009. She currently holds a Future Coastlines post-doctoral research fellowship at Griffith University. Her present research interests include remote sensing of the nearshore ocean, coastal processes and morphological evolution of the nearshore environment.

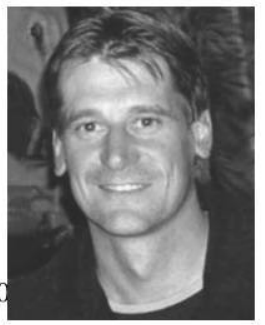

Darrell R. Strauss received the B.Sc. degree in meteorology and oceanography from Flinders University of South Australia, Adelaide, Australia, in 1992. He completed a graduate certificate in research management at the Southern Cross University, Lismore, Australia in 2009 and received the Ph.D. degree at Griffith University, Gold Coast, Australia in 2010. He has been employed as a Research Fellow with the Griffith Centre for Coastal Management, Griffith University, Australia since 2006. His research interests include impacts of climate variability on the morphodynamics of beaches and tidal inlets.

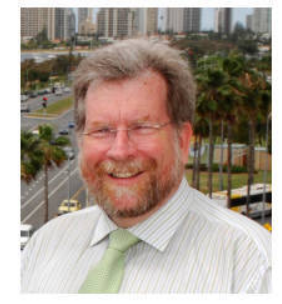

Rodger B. Tomlinson received the B.E. degree in civil engineering from the University of New South Wales in 1977 and the Ph.D. degree in Coastal Engineering from UNSW in 1986. He has been at Griffith University since 1992 in the role of Head of School of Environmental Engineering, and since 2000 as the Foundation Director of the Griffith Centre for Coastal Management based on the Gold Coast Campus.

His current research interests concentrate on the planning and management for natural variability on open coastlines. This has included historical and process studies of the impact of climate change and climate variability on coastlines, tidal entrances and coastal waterways. He is the program leader for a major Queensland Smart State Research-Industry Partnership grant entitled Future Coastlines - Modelling the Impact of Extreme Events. He is the Coastal Program Leader for the Griffith Climate Response Program and is the Coastal Node Convenor for the Australian Climate Change Adaptation Research Network for Settlements and Infrastructure. 

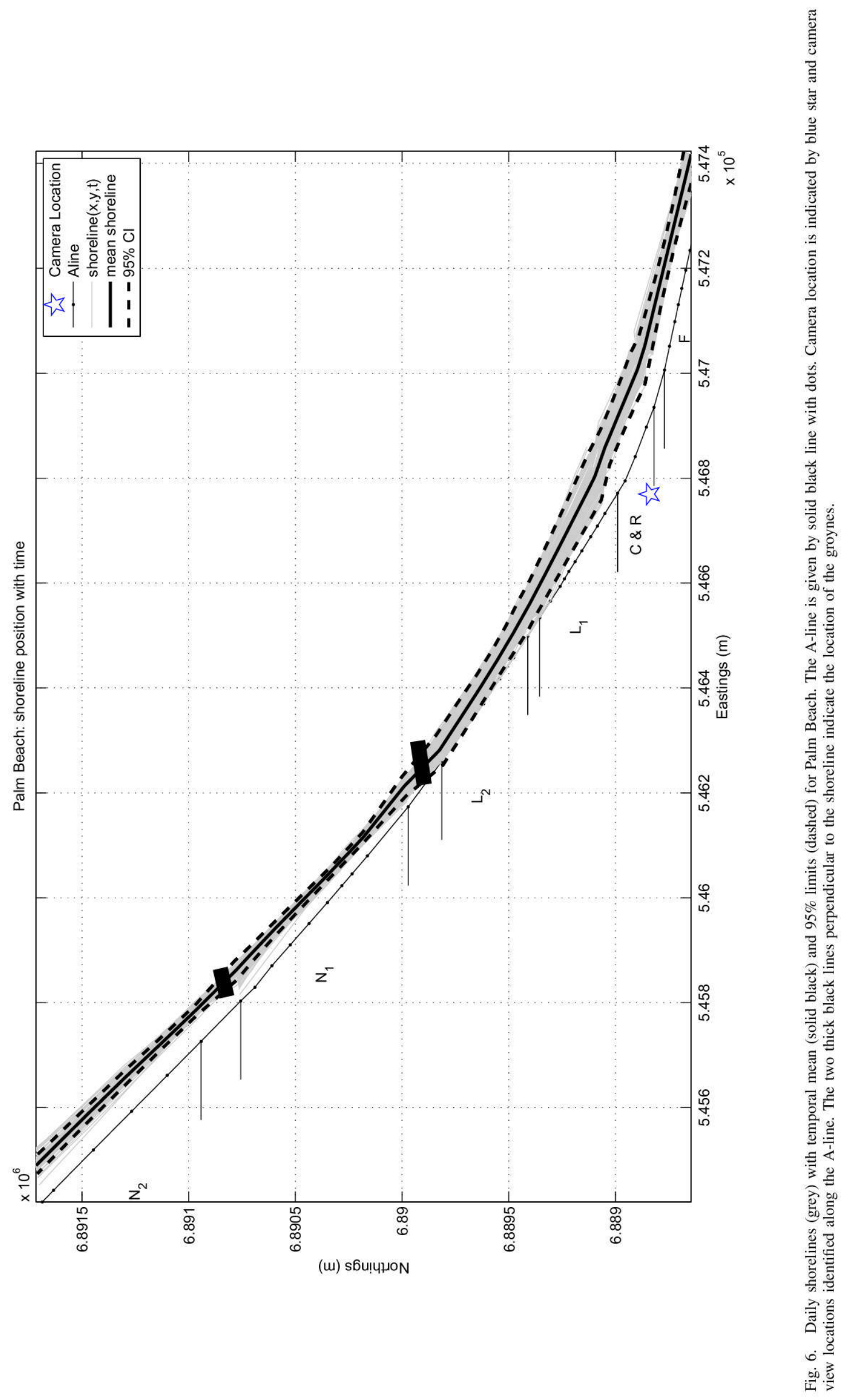